ks. Kazimierz Panuś

\title{
Przesłanie Ojców Kościoła dla współczesnego kaznodziejstwa
}

Czy Ojcowie Kościoła, wielcy świadkowie tradycji pierwszych wieków chrześcijaństwa, mogą jeszcze czegoś nauczyć współczesnego kaznodzieję? Czy przy przepowiadaniu Ewangelii warto sięgać do ich tekstów? W czym współczesny kaznodzieja może ich naśladować? Na te pytania nadal odpowiedź jest jednoznaczna: warto, a nawet należy. I to nie dlatego, by naszym myślom nadać powagę ich autorytetu, lub dlatego, że chrześcijaństwo zawsze do nich powracało.

Jednoznacznie na ten temat wypowiada się Urząd Nauczycielski Kościoła ostatnich lat. Niekwestionowany jest autorytet Ojców Kościoła, „prawdziwych mistrzów”, których nauka nadal pozostaje aktualna - stwierdza Instrukcja Kongregacji ds. Wychowania Katolickiego O studium Ojców Kościoła $w$ formacji kaptańskiej ${ }^{1}$. Z kolei w dokumencie Kongregacji ds. Duchowieństwa pt. Kapłan głosiciel stowa, szafarz sakramentów i przewodnik wspólnoty w drodze do trzeciego tysiąclecia chrześcijaństwa czytamy: „Zawsze trzeba pamiętać, że pisma Ojców Kościoła i innych wielkich pisarzy Tradycji pomagają nam zgłębiać objawione słowo i przybliżać je wiernym"2.

Doniosłość patrystycznego nauczania podkreślał papież Jan Paweł II. W liście apostolskim na 1600-lecie śmierci świętego Bazylego stwierdzał: „Tak więc byli oni [Ojcowie Kościoła] i pozostają na zawsze Ojcami, sami bowiem są jakby stałą konstrukcją Kościoła i poprzez wszystkie wieki pełnią dla Kościoła wierną służbę. Stąd też każde następne głoszenie Ewangelii i nauczanie, jeśli chce być autentyczne, musi być uzgodnione z ich nauczaniem, każdy charyzmat i każdy urząd musi czerpać z żywego źródła ich ojcostwa"3.

${ }^{1}$ Instrukcja Kongregacji ds. Wychowania Katolickiego, O studium Ojców Kościoła w formacji kapłańskiej, „Vox Patrum” 10 (1990) t. 18, s. 20.

${ }^{2}$ Kongregacja ds. Duchowieństwa, Kaptan głosiciel słowa, szafarz sakramentów i przewodnik wspólnoty w drodze do trzeciego tysiaclecia chrześcijaństwa, Tarnów 1999, s. 34.

${ }^{3}$ Jan Paweł II, List apostolski na 1600-lecie śmierci świętego Bazylego Patres Ecclesiae, „Vox Patrum” 2 (1980) t. 3, s. 247-248. 
Aktualność Ojców Kościoła podkreślają też teologowie i znawcy literatury wczesnochrześcijańskiej. „Wielkim niebezpieczeństwem - pisze ks. prof. Marek Starowieyski - byłoby odcięcie się od strumienia tradycji, a szczególnie od górnego biegu tego strumienia, którym są właśnie Ojcowie Kościoła"5.

Przesłanie, jakie kierują do współczesnego kaznodziei Ojcowie Kościoła, polega - moim zdaniem - na zwróceniu uwagi na trzy istotne wymiary przepowiadania. Wielcy kaznodzieje starożytności chrześcijańskiej uwrażliwiają na podstawowe źródło przepowiadania, jakim jest Pismo Święte, domagają się komunikatywnego przekazu słowa Bożego i podkreślają ścisły związek skuteczności głoszenia słowa Bożego z wysokim poziomem życia religijnego i moralnego kaznodziei ${ }^{6}$.

\section{Pismo Święte źródłem przepowiadania}

Pouczenia moralne i refleksje teologiczne opierali Ojcowie Kościoła na Piśmie Świętym. Było ono w centrum ich zainteresowań. Księgi Starego i Nowego Testamentu czytywali stale, wiele z nich znali na pamięć. Zarówno ich myśl, jak i język były nasycone Biblią․ „Ojców odnajdujemy w domu Pisma Świętego, bo oni zawsze zapraszają na ucztę przygotowaną przez autorów Biblii" - pisze ks. prof. Edward Staniek ${ }^{8}$.

Kaznodzieja każdej epoki, udając się do szkoły biblijnej Ojców Kościoła, łatwo może się przekonać, że Pismo Święte nie było dla nich jakimś spisanym dokumentem, lecz obecnością Boga wśród ludzi. W Piśmie Świętym szukali z całą miłością Boskiego Oblubieńca, starając się przebić przez „zasłonę” ludzkiego słowa i dotrzeć do ukrywającego się pod nią Słowa Wcielonego.

${ }^{4}$ Zob. m.in. L. Małunowiczówna, Aktualność Ojców Kościoła, [w:] Z zagadnień kultury chrześcijańskiej, red. K. Wojtyła, Lublin 1973, s. 137-146; E. Stanula, Ojcowie Kościoła naszymi nauczycielami?, [w:] Chrześcijaństwo żywych, pr. zb. pod red. B. Bejzego, Warszawa 1976, s. 83-100; M. Starowieyski, Ojcowie, których można czytać, „,Tygodnik Powszechny” 3 (1977); M. Pellegrino, Czy Ojcowie Kościoła mają coś do powiedzenia współczesnemu człowiekowi?, „Vox Patrum” 9 (1989) t. 16, s. 111-120.

${ }^{5}$ M. Starowieyski, „Karmię Was tym, czym sam żyję”. Ojcowie Kościoła komentują ewangelie niedzielne roku A, Kraków 1978, s. 6. W opracowaniu tego autora ukazały się jeszcze pozostałe tomy: „Karmię Was tym, czym sam żyję”. Ojcowie Kościoła komentują ewangelie niedzielne roku B, Kraków 1979; „Karmią Was tym, czym sam żyję”. Ojcowie Kościoła komentują ewangelie niedzielne roku C, Kraków 1980.

${ }^{6}$ E. Stanula, Ojcowie Kościoła naszymi nauczycielami?, art. cyt., s. 96, zauważa podobnie: „Trzy elementy widziałbym w pismach Ojców, które zadecydowały o ich modelowej roli w accomodata renovatio Kościoła każdej epoki: język, biblijny charakter ich pism, koncepcja uprawiania teologii”.

${ }^{7}$ Por. L. Małunowiczówna, Aktualność Ojców Kościoła, [w:] Z zagadnień kultury chrześcijańskiej, red. K. Wojtyła, Lublin 1973, s. 142.

${ }^{8}$ E. Staniek, Mądrość starożytnych chrześcijan, Kraków 2007, s. 6. 
Całą spuściznę literacką Ojców można traktować jako jeden wielki komentarz do Pisma Świętego, za jedno dzieło interpretacyjne Boskiego Objawienia. Słowa Biblii stanowią centrum ich natchnienia, myślenia i życia. Nieraz cytaty czy aluzje stanowią zasadniczą tkankę ich kazania czy traktatu. Św. Ambroży np. opiera na Piśmie Świętym swoją naukę moralności. Św. Augustyn tworzy model kultury chrześcijańskiej, wprowadzając w jej centrum właśnie Pismo Święte. Wielkimi entuzjastami Biblii byli też Orygenes, św. Hieronim i św. Jan Chryzostom. Twórca Wulgaty stwierdza kategorycznie: „Nieznajomość Pisma Świętego jest nieznajomością Chrystusa". Z kolei Jan Złotousty zaklinał świeckich, by posiadali na własność Pismo Święte: „Jeśli nie chcecie czego innego, nabądźcie przynajmniej Nowy Testament, Dzieje Apostolskie, Ewangelię jako nauczycieli na całe życie [...]. To jest przyczyna wszystkich nieszczęść: nieznajomość Pisma. Bez oręża idziemy na wojnę"10.

To prawda, że niejednokrotnie symboliczna interpretacja Pisma Świętego dawała możliwość snucia fantastycznych objaśnień, które żadną miarą nie da się pogodzić ze współczesną egzegezą, ale dzisiejszy kaznodzieja, który często nie przeczytał całej Biblii ani raz, musi chylić głowę z szacunku dla pierwszych egzegetów w historii Kościoła.

W myśl jednej z najstarszych definicji kaznodzieja winien być przede wszystkim „badaczem Pisma Świętego i uczonym” (tractator divinarum scripturarum et doctor), jak to ujął w De doctrina christiana św. Augustyn. Zdaniem biskupa Hippony dopiero taki kaznodzieja, który pozna słowo Boże, będzie mógł być - w myśl dalszej części tej definicji - „obrońcą prawdziwej wiary i pogromcą błędów, powinien zarówno uczyć dobrego, jak odzwyczajać od złego, wymową zaś godzić skłóconych, pobudzać opieszałych, nieświadomych uczyć jak mają postępować i czego oczekiwać"11.

Augustyn pragnął, by kaznodzieja, według pięknego określenia zawartego w jego Sermo 288, był „głosem Słowa” (vox Verbum). Chcąc jednak być „głosem Słowa”, każdy kaznodzieja winien być wpierw „słuchaczem

9 „Ignoratio Scripturarum, ignoratio Christi est” - S. Eusebii Hieronymi stridonensis presbyteri Commentariorum in Isaiam Prophetam libri duodeviginti, prologus, 1, [w:] Sancti Eusebii Hieronymi stridonensis presbyteri Opera Omnia, accurante J. P. Migne, t. 4, Parisiis 1845, kol. 17B (Patrologiae cursus completus. Series Latina, 24).

${ }^{10}$ Homilia 9, 1 do Listu do Kolosan, 3.

${ }^{11}$ S. Augustini, De doctrina christiana IV, 4. 6: „Debet igitur divinarum scripturarum tractator et doctor, defensor rectae fidei ac debellator erroris, et bona docere et mala dedocere, atque in hoc opero conciliare aduersos, remissos erigere, nescientibus qouod agitur, quid exspectare debeant intimare"; tłum. polskie: św. Augustyn, O nauce chrześcijańskiej, thum. J. Sulowski, Warszawa 1979, s. 101. 
Słowa"12. Winien więc ukochać Pismo Święte, stale je zgłębiać i rozważać. Dlatego biskup Hippony będzie przypominał swoim wiernym, że jest on podobnie jak oni i wraz z nimi uczniem i słuchaczem słowa Pańskiego, zanim podejmie obowiązek jego przekazu. W dwunastej księdze swoich Wyznań, snując refleksję na temat słowa Bożego, zauważa: „Jakże cudowna jest głębia Twoich słów! Patrzymy na ich powierzchnię, która się do nas jak do dzieci uśmiecha. Lecz pod nią, Boże mój, jakaż głębia, jakaż cudowna głębia! Lęk ogarnia, gdy się wejrzy w nią, cześć pełna lęku, miłość pełna drżenia" (Wyznania XII, 14). Słowo Pisma Świętego jest jak lampa w nocy tego świata, jak parę kropli z niewyczerpanego źródła Bożej mądrości ${ }^{13}$.

\section{Troska o komunikatywność języka kaznodziejskiego}

Od Ojców Kościoła współczesny kaznodzieja może się wiele nauczyć w umiejętności komunikatywnego przekazu słowa Bożego. Język Ojców jest przede wszystkim językiem biblijnym, to jest prostym, zdolnym zaprowadzić zarówno początkujących na drogę wiary, jak i zaawansowanych obdarzyć głębokim zrozumieniem już wyznawanej wiary. Jest to język opowiadający fakty z życia Chrystusa, z dziejów historii zbawienia. Nie tyle określa on nadprzyrodzoną rzeczywistość, ile na nią wskazuje - podkreślał redemptorysta Emil Stanula ${ }^{14}$.

W miarę rozwoju refleksji nad treścią Biblii oraz rozszerzania się chrześcijaństwa biblijny język nadal utrzymuje się w pismach Ojców poprzez jego adaptację do środowiska kulturowego. Ojcowie wykazują w tym względzie nieprzeciętny wysiłek w wiernym przetłumaczeniu języka biblijnego na język im współczesny. Z każdej dziedziny życia kulturowego czerpią terminy, nadając im znaczenie ewangeliczne. Wykuwają nowe pojęcia.

${ }^{12}$ Por. I. Bochet, L'expérience spirituelle du prédicateur selon s. Augustin, „Connaissance des Pères de l'Église" 74 (1999), s. 49-50.

${ }^{13}$ Św. Augustyn, Homilia na Ewangelię św. Jana 35, 8-9: „Przyjdziesz do źródła, zobaczysz światłość... Gdy zatem przyjdzie Pan nasz Jezus Chrystus i rozjaśni - jak mówi apostoł Paweł - to co ukryte w ciemnościach oraz ujawni zamiary serc, aby każdy otrzymał pochwałę od Boga, wtedy w obliczu tak jasnego dnia przestaną być potrzebne pochodnie; nie będziemy czytać proroctw ani otwierać pism Apostołów, nie będziemy szukać świadectwa Jana, nie będziemy potrzebować nawet Ewangelii. Wszystkie zatem Pisma świecące jak lampy w nocy tego świata, abyśmy nie trwali w ciemnościach, zostaną wtedy usunięte... Oto staniesz u źródła, z którego otrzymałeś dotąd parę kropel. Oto ujrzysz odsłonięte światło, którego jeden promień przez zakola i załamania dotarł do pogrążonego w mrokach twego serca. Za chwilę odłożę Księgę, a wy rozejdziecie się do swego domu. Było nam dobrze cieszyć się Nim i radować; teraz więc oddalając się jedni od drugich, obyśmy nie oddalili się od Niego".

${ }^{14}$ Por. E. Stanula, Ojcowie Kościoła naszymi nauczycielami?, art. cyt., s. 96. 
Przy całym tym wysiłku zmierzają do tego, by w przepowiadaniu Ewangelii być zrozumiałymi dla wszystkich, zarówno dla katechumenów, jak dla żyjących już w pełni nadprzyrodzonym życiem. Większość Ojców była znakomitymi retorami. Głosili homilie i kazania według zasad retoryki. Ale wygłaszając je, pamiętali, że mają przed sobą nie tylko wykształconych słuchaczy. Św. Augustyn starał się głosić kazania językiem zrozumiałym także dla prostaczków, świadomie rezygnując, a była to wielka ofiara ze strony dawnego profesora wymowy, z pięknej formy słowa. Znane jest jego powiedzenie: „Lepiej jest, by nas ganili gramatycy, niż żeby nie rozumieli ludzie".

Podobna troska o zrozumiały wykład przekazywanych ludowi treści towarzyszyła św. Cezaremu z Arles. W Sermo 86, 1 stwierdza: „Ponieważ nieuczeni i prostacy nie mogą podnieść się na poziom wysokich uczonych, niech więc wykształceni będą łaskawi zniżyć się do ich niewiedzy, bo to co powie się prostaczkom, zrozumieją i uczeni, a tego, co się wygłosi dla uczonych, prostaczkowie nie będą w stanie pojąć".

Jakżeż bardzo powinien sobie wziąć do serca te słowa współczesny kaznodzieja, który w pracy na ambonie często sięga do warsztatu naukowego teologa, do słownictwa specjalistycznego, którego czasem sam nie rozumie. Nim karmi swych słuchaczy osiągając mizerne rezultaty. Jakżeż bardzo do głosu powinien dojść „,kierunek narracyjny”, który uwalnia wiarę z definicji metafizycznych i formułek katechizmowych i powraca do jej pierwotnego dynamicznego kształtu - do formy „opowieści”. Bóg bowiem nie objawił się nam w postaci gotowego systemu naukowego.

Duszpasterska troska o przepowiadanie treści Boskiego Objawienia językiem zrozumiałym widoczna jest nawet w poważnych traktatach teologicznych Ojców. Konieczność bycia zrozumianym przez lud prosty skłaniała Augustyna do precyzji językowej, do wykładu obszernego podanego z najdrobniejszymi szczegółami, do częstego posługiwania się żywymi obrazami i niezapomnianymi przykładami. Innymi słowy, Augustyn potrafił w swoich kazaniach być jednocześnie analitykiem i syntetykiem: analitykiem, żeby oddać głębię myśli, syntetykiem, żeby ująć ją w formuły niejednokrotnie tak charakterystyczne, że zdają się być przysłowiami. Oto jeden z przykładów. W kazaniach i w dziele De Trinitate znajdują się te same zagadnienia dotyczące Trójcy Świętej: nierozdzielność w działaniu ad extra, pochodzenie osób boskich, wzajemne relacje między nimi, wyjaśnienie psychologiczne, transcendencja i kontemplacja mistyczna tajemnicy, przymioty osób wewnątrz Trójcy Świętej oraz objawienia Jej w historii zbawienia.

Mówiąc o biblijnym języku Ojców jako normie czy wzorze dla wszystkich kaznodziejów, nie chcę powiedzieć, że jest on łatwy, że nie nastręcza nam żadnych trudności. Chciałbym tylko stwierdzić, że kiedy Ojcowie pisali 
i przemawiali, byli rozumiani. Chcę także podkreślić, że specjalistyczny, wprost techniczny język powoduje - jak wskazuje historia - wspaniały rozwój dyscyplin teologicznych, ale równocześnie upadek życia religijnego.

Ojcowie Kościoła uczą umiejętnego sięgania po obrazy, metafory, egzempla, które wyjaśniają i przybliżają omawiana problematykę. Wspólną cechą obrazu jest to, że zastępuje rzeczywistość, że do niej odsyła i w tym sensie ją symbolizuje. Język i obraz w równym stopniu są „nośnikami” znaczenia, znakami stworzonymi przez człowieka dla czegoś, co istnieje na zewnątrz, poza znakiem, w tzw. świecie właściwym.

Oto, jak św. Hieronim tłumaczy w kazaniu do nowo ochrzczonych na temat Ps 41 różnicę między chrześcijaninem a nieochrzczonym: „Wy przeto, którzy przyodzialiście się teraz w Chrystusa i podążając za naszymi wskazaniami zostaliście wyciągnięci Bożym słowem jak ryby z odmętów tego świata, powiedzcie: Oto w nas odwrócony został naturalny bieg rzeczy. Gdy bowiem wyciąga się ryby z morza, umierają. Nas jednak Apostołowie złowili i wyciągnęli z morza tego świata, abyśmy ze śmierci przeszli do życia. Dopóki byliśmy w świecie, nasz wzrok kierował się ku temu, co na dole, a życie nurzało się w błocie. Skoro jednak zostaliśmy wydobyci z odmętów, ujrzeliśmy słońce, zaczęliśmy oglądać prawdziwą światłość, i ogarnięci niezwykłą radością, mówimy duszy naszej: «Ufaj Bogu, albowiem wysławiać Go będę, zbawienie mojego oblicza i mego Boga»”.

Pełne przykładów wziętych z życia są kazania św. Jana Chryzostoma. W Kazaniu na Epifanię w sposób niezwykle prosty uzasadnia potrzebę świętowania dnia Pańskiego, a argumentacja ta nie straciła nic ze swej aktualności: „Siedem dni ma tydzień i tymi siedmioma dniami Bóg się z nami podzielił. Nie zatrzymał dla siebie większej, a nam nie oddał części mniejszej, nawet równo nie podzielił się z nami, nie wziął dla siebie trzech i nie trzy dni nam oddał, lecz tobie dał sześć, sobie zaś zatrzymał tylko jeden. A jednak nie chcesz tego zrozumieć i w tym jednym dniu nie chcesz całkowicie wstrzymać się od zajęć ziemskich, nie wstydzisz się, że dzień ten spędzasz jak złodziej, co okrada kościół! Kradniesz bowiem ten uświęcony i na wysłuchanie Boskiego słowa przeznaczony dzień, aby wykorzystać go do zajęć świątecznych. Po cóż mówię o całym dniu? Ofiaruj Panu choć małą cząstkę tego dnia, podobną do skromnej jałmużny, jaką ofiarowała wdowa! Jak ona dała dwa grosze i tym zyskała sobie upodobanie Boże, tak i ty poświęć Bogu dwie godziny, a tak pójdziesz do domu z zyskiem, który zrównoważy dni tysiąc".

Przed słuchaczami Jan z Antiochii przesuwał barwny obraz codzienności. Tylko w jednym Kazaniu na Zielone Światki można spotkać takie porównania kaznodziejskie: „Jak ze zjawieniem się słońca pierzchają ciemności, zwierzęta kryją się, zbójcy uciekają; tak ze zjawieniem się Piotra 
znikły ciemności, uciekli szatani”. [...] „Jak ogień, ogarnąwszy miękką glinę, uczyni z niej twardą cegłę, tak i ogień Ducha Świętego złą duszę, choćby była bardziej miękka od gliny, uczyni twardszą od żelaza” [...] „Miłość jest korzeniem, źródłem i matką wszelakich dóbr, bo jak korzeń, wypuszcza liczne gałęzie, cnoty, gdyż jak źródło, rodzi rozliczne strumienie - i jak matka, bo tuli do łona uciekających się do niej”. W epoce mediów można uczyć się od Ojców techniki obrazowania.

Wielu Ojców czyta księgę natury w homiliach komentujących biblijne sześć dni stworzenia i na tym przykładzie uczyło podziwu dla mądrości Boga - Stwórcy.

\section{Karmię was tym, czym sam żyję}

Ojcowie Kościoła byli duszpasterzami świadomymi odpowiedzialności za ludzi sobie powierzonych i - jak św. Jan Chryzostom - podejmowali z lękiem i odpowiedzialnością pracę duszpasterską. W swych kazaniach i homiliach przekazywali ludziom wyniki modlitewnej lektury Pisma Świętego, ich pokarmu duchowego. W tej ogromnej pracy komentatorskiej nad Pismem Świętym za najistotniejszy element metody egzegetycznej prowadzącej do zrozumienia Objawienia Ojcowie uważali modlitwę. Pismo Święte jest księgą Boga, Jego też należy prosić o jej otwarcie. Orygenes, pisząc do Grzegorza Cudotwórcy, z naciskiem podkreśla: „Przystępując do lektury Bożej, staraj się przede wszystkim doszukiwać w duchu wiary tego, co uchodzi uwagi wielu, mianowicie duchowego sensu Pisma świętego. Nie zadowalaj się samym tylko jego zewnętrznym opukaniem i przeanalizowaniem. Najważniejszym środkiem do zrozumienia słów Bożych jest modlitwa" ${ }^{15}$. Czytając homilie św. Augustyna do Ewangelii św. Jana, jesteśmy wprost znużeni ciągłym apelem do modlitwy.

Słowo Boże głoszone przez Ojców Kościoła szło zawsze w parze z przykładem ich życia. Niewielu kaznodziejów w całej historii potrafiło tak jak św. Augustyn wiązać uwagę słuchaczy. Ale wpływu, jaki wywierały jego słowa, nie da się wytłumaczyć samym tylko jego geniuszem czy sztuką oratorską ani nawet jego wyjątkową wrażliwością, która pozwalała mu w sposób wręcz bezpośredni złączyć się ze słuchaczami i przeczuwać ich reakcje. Jego słowa wypływały z serca, wyrażały to, czym sam żył. Podkreślał: „Karmię was tym, czym sam żyję” (Sermo 329, 3), a w innym kazaniu dodawał: „Podaję wam pokarm, dzięki któremu żyję sam, na wasz stół stawiam pokarmy, którymi ja sam się sycę. Ja jestem sługą, a nie panem domu” (Sermo 399, 4).

${ }^{15}$ Remerciement à Origène, suivi de la Lettre d'Origène à Grégoire, texte grec, introduction, traduction et notes par H. Crouzel, Paris 1969, s. 193n (Sources Chrétiennes, 148). 
O powodzeniu kazania decydują - zdaniem autora De doctrina christiana - nie tylko zdolności krasomówcze i mądrość kaznodziei, ale jego osobowość i sposób życia. Jeżeli kaznodzieja żyje nienagannie, to nawet treściowe i formalne usterki w kazaniu nie zrażą doń wiernych. Głosiciel słowa Bożego musi się wszechstronnie przygotować do swoich zadań, aby potrafił przedstawiać prawdę, dobierać argumenty, przy pomocy których zdoła rozwiać wątpliwości słuchaczy i nakłonić ich do uległości wobec prawdy Bożej ${ }^{16}$.

Ojcowie Kościoła niestrudzenie przypominają kaznodziejom wszystkich czasów, iż mają być oni ludźmi modlitwy i kontemplacji, a podstawowym ich zadaniem w tym życiu jest leczyć oczy serca, tak aby mogły coraz lepiej widzieć Boga. „Tota igitur opera nostra, fratres, in hac vita est, sanare oculum cordis, unde videatur Deus" (Sermo 88, 5; PL 38, 542) - powie św. Augustyn. Dopiero wówczas kaznodzieja będzie mógł być „głosem Słowa”, gdy wpierw będzie jego słuchaczem. Augustyn doskonale ilustruje to, wyciągając wnioski z analizy obrazu aniołów wstępujących i zstępujących po drabinie Jakubowej. ,Jakub widział we śnie drabinę, a na stopniach aniołów wstępujących i zstępujących [...]. Co zaś wtedy widział na stopniach? Wstępujących i zstępujących aniołów. Tak, bracia, dzieje się i z Kościołem. Aniołami Boga są dobrzy głosiciele, głoszący Chrystusa; wstępują i zstępują oni ponad Syna Człowieczego. [...] Jeśli sam Pan wstąpił i zstąpił, to jasne, iż Jego głosiciele wstępują, aby Go naśladować, zstępują, żeby Go głosić"17. Kaznodzieje wstępują, by kontemplować Chrystusa, zstępują, aby Go głosić. Wstępują ku Chrystusowi Głowie, zstępują kierując się ku Chrystusowi obecnemu w członkach. W ten sposób nie oddalają się oni nigdy od Chrystusa. Skoro więc Chrystus przemawia przez kaznodziejów i jest też obecny w swoich słuchaczach, Augustyn nie waha się stwierdzić, że to „Chrystus sam naucza”18. Tak pojęte kaznodziejstwo jest całkowicie chrystocentryczne.

\section{Zakończenie}

Doskonały kształt kazania grecko-rzymskiego wypracowany w złotym okresie patrystycznym był wynikiem akceptacji warsztatu starożytnego retora, który dawał możliwość nauczenia się piękna i kultury ukrytej w prostocie przekazu prawdy.

Spuścizny kaznodziejskiej Ojców Kościoła nie można przyjmować bezkrytycznie, nie można też jej odrzucać w imię nowoczesności. To

${ }^{16}$ Por. K. Panuś, Historia kaznodziejstwa, Kraków 2007, s. 80.

${ }^{17}$ S. Augustini, In Johannis Evangelium Homilia 7, 23, [w:] św. Augustyn, Homilie na Ewangelie i Pierwszy List św. Jana, cz. 1, Warszawa 1977, s. 131-132.

${ }^{18}$ S. Augustini, Enarrationes In Ps. 74, 4; PL 39, 1027. 
prawda, że nie wszyscy kaznodzieje reprezentowali tak wysoki poziom. Wielu było przeciętnych i słabych. Prawdą jest jednak, że wielcy mówcy Chrystusowego Kościoła byli niczym kamienie milowe wyznaczające na długie lata, niejednokrotnie nawet wieki, kierunki poszukiwań nowych form kaznodziejskich i owocnego przekazu słowa Bożego. W ślad za nimi szli inni głosiciele prawdy Bożej.

Z lektury kazań i homilii Ojców Kościoła nadal można się uczyć głoszenia słowa Bożego w sposób żywy, popularny, poglądowy, aktualny i głęboki. Ojcowie Kościoła żyją Pismem Świętym przemyślanym, przemodlonym i do głębi poznanym. Z nim w ręku próbują zrozumieć otaczający świat i znaleźć w nim miejsce dla siebie i powierzonych im ludzi. Pismo Święte wrasta w ich kaznodziejstwo i z niego wyrasta. Słuchają go pilnie, bo jest to słowo Boże skierowane do nich. To, czym karmią swych słuchaczy, wspierają czytelnym świadectwem swego życia.

Kraków

KS. KAZIMIERZ PANUŚ

\section{Słowa kluczowe}

Kazania i homilie Ojców Kościoła; Pismo Święte; przepowiadanie współczesne.

\section{Summary}

\section{The message of the Fathers of Church for the contemporary preaching}

By reading the sermons and homilies of the Fathers of Church worked out in the golden patristic period one can still learn how to advocate the word of God in a vivid, popular, illustrative, current and profound way. The Fathers of Church are absorbed in the Holy Scriptures, well-thought-out, prayed for and deeply studied. Holding the Holy Scriptures in hand they try to understand the world around and to find a place for themselves as well as for the people entrusted to them. They diligently listen to the Holy Scriptures because it is the Word of God directed also to them. What they give to their listeners is supported by clear testimony of their lives.

\section{Key words}

Sermon, homily, Fathers of Church, the Holy Scriptures, contemporary preaching 
